удк 338.2

DOI: https://doi.org/10.32851/2708-0366/2021.10.11

Павленко В.Я.

старший науковий співробітник,

Український науково-дослідний інститут спеціальної техніки та судових експертиз Служби безпеки України

ORCID: $h$ ttps://orcid.org/0000-0003-0925-4173

Pavlenko Vyacheslav

The Ukrainian scientific and research Institute of special equipment and forensic expertise of the Security Service of Ukraine

\title{
СЕРТИФІКАЦІЙНІ ВИПРОБУВАННЯ ЯК ІНСТРУМЕНТ ПІДВИЩЕННЯ ЯКОСТІ ПРОДУКЦІЇ
}

\author{
CERTIFICATION TESTS \\ AS A TOOL TO IMPROVE PRODUCT QUALITY
}

У статті проаналізовано класифікаиію сертифікаційних випробувань як важсливого етапу підтвердження відповідності продукиії стандартам якості, а також основні роботи, що виконуються у прочесі сертифікачії. Розгляд та аналізування підвищення якості продукиї, ще виготовляється вітчизняними виробниками, - далеко не нове питання. Поступовий перехід до ринкової економіки у сфері виробництва призвів до стрімкого зростання кількості самостійних виробниитв, ослаблення державного контролю за якістю та безпечністю товарів та зростання ризиків виготовлення неякісної продукиї. У сучасних умовах процес підвищення якості стає набагато складнішим та таким, що може потребувати значних зусиль. Саме тому у сьогоденній ринковій конкуренції широкого поширення набуває послуга сертифікаційних випробувань товарів та послуг. Особливої актуальності в умовах ринкових відносин, коли вітчизняним підприємствам та організачіям різних форм власності надане право самостійного виходу на зовнішній ринок, набуває проблема оцінювання якості та надійності своєї продукиії. Для вироблення високоякісної продукиії на всіх стадіях ї̈ життевого ииклу необхідно визначити точний механізм незалежного підтвердження якості та безпечності продукції, процесу або послуги. Тому разом із традииійними методами та засобами забезпечення якості та безпечності продукції найбільш ефективним способом гарантування якості продукиії і послуг та відповідності їх установленим вимогам є сертифікація - оцінювання третьою стороною. Для досягнення своїх иілей учасники ринкових відносин, а саме виробник та споживач, можуть використовувати як закономірні розбіжності результатів сертифікаиійних випробувань, так $і$ більи вигідні певній стороні процедури очінки відповідності. Тільки за допомогою сертифікаціі можна надати письмову гарантію, що продукиія, послуга чи процес відповідають указаним вимогам. Основним завданням сертифікаційних випробувань є можливість визначити здатність продукиії виконувати очікувані функиії в певних умовах иляхом отримання ї̈ якісних або кількісних характеристик дослідницькими методами.

Ключові слова: процес, сертифікаційні випробування, продукиія, оијнювання, послуга, сертифікаційні вимоги, вимога до продукції, орган із сертифікації.

В статье проанализирована классификаиия сертификаиионных испытаний как важный этап подтверждения соответствия продукиии стандартам качества, а также основные работы, выполняемые в прочессе сертификаиии. Рассмотрение и анализ повышения качества продукиии, производимой отечественными производителями, - далеко не новый вопрос. Постепенный переход к рыночной экономике в сфере производства привел к стремительному росту количества самостоятельных производств, ослаблению государственного контроля качества и безопасности товаров и росту рисков изготовления некачественной продукиии. В современных условиях процесс повышения качества становится намного сложнее и может потребовать значительных усилий. Именно поэтому в рыночной конкуренции широкое распространение получает услуга сертификационных испытаний товаров и услуг. Особую актуальность в условиях рыночных отношений, когда отечественным предприятиям и ор- 
ганизачиям разных форм собственности предоставлено право самостоятельного выхода на внешний рынок, приобретает проблема оценки качества и надежности продукции. Поэтому вместе с традиционными методами и средствами обеспечения качества и безопасности продукции наиболее эффективньм способом гарантирования качества продукции и услуг и соответствия их установленным требованиям является сертификация - оценка третьей стороной. Для достижения свочх иелей участники рыночных отношений, а именно производитель и потребитель, могут использовать как закономерные расхождения результатов сертификационных испьтаний, так и более выгодные определенной стороне процедуры оценки соответствия. Только с помощью сертификации можно предоставить письменную гарантию, что продукция, услуга или процесс отвечают указанньм требованиям. Основной задачей сертификаиионных испьтаний является возможность определить способность продукции выполнять ожидаемые функции в определенных условиях путем получения ее качественных или количественных характеристик исследовательскими методами.

Ключевые слова: процесс, сертификационные испьтания, продукиия, оценка, услуга, сертификационные требования, требования к продукичи, орган по сертификации.

The contribution compounds the classification of certification tests as an important stage in confirming validations of products to quality standards, as well as the main work that is carried out in the certification process. Consideration and compounds of the product quality improvement, which is produced by domestic manufacturers, is far from a new topic. The progressive junction to a market-driven economy in the area of production facilities led to a rapid increase in the number of independent industries, the absence of state supervision over the quality and safety of goods and an increase in the risks of manufacturing low-quality products. Under presentday conditions, the process of improving quality is becoming more complex and such that it can require significant efforts. That is why certification testing services are widely spread in today's market competition. Of particular relevance in the conditions of market relations, when domestic enterprises and companies of various forms of ownership are given the right to independently enter the foreign market, the problem of assessing the quality and reliability of their products arises. To manufacture high-quality products at all stages of their life cycle, it is necessary to determine the exact mechanism for the proper confirmation of the quality and safety of a product, process or service. Therefore, along with traditional methods and means of ensuring the quality and safety of products, the most effective way to guarantee the quality of products and services and their compliance with established requirements is certification - an assessment by a third party. To achieve their goals, market participants, namely the manufacturer and the consumer, can use both regular discrepancies in the results of certification tests and conformity assessment procedures that are more beneficial to a certain party. Certification alone can provide written assurance that a product, service or process meets specified requirements. The main task of certification tests is the ability to determine the ability of products to perform expected functions under certain conditions, by obtaining its qualitative or quantitative characteristics by research methods.

Key words: process, certification tests, product, evaluation, service, certification requirement, product requirement, certification center.

Постановка проблеми. Формування конкурентоспроможності на ринку підприємств починається з перегляду підходів до забезпечення якості продукції, що виробляється, та актуальності проведення аналізу організації сертифікаційних випробувань різноманітних товарів, тому потрібно визначити шляхи вдосконалення розвитку підприємництва. Детальне вивчення та дотримання затвердженої процедури сертифікації дасть змогу виробникам удосконалити власне виробництво Наслідком цього стане підвищення рівня конкурентоспроможності продукції та послуг на світовому ринку.

Аналіз останніх досліджень і публікацій. Дослідженням проблемних питань аналізування ризиків займалися такі вітчизняні науковці, як Р. Олексенко, Г. Цилюрик, І. Кононенко та ін. Серед закордонних досліджень заслуговують на увагу праці М. Брауна, Т.Я. Селіванової, В.І. Шевельової.

Водночас, незважаючи на значну кількість наукових публікацій, присвячених проблемам підвищення конкурентоспроможності вітчизняних підприємств, перегляд підходів до забезпечення якості продукції, що виробляється, зумовлює потребу подальших досліджень цієї тематики. 
Формулювання цілей статті. Метою статті є дослідження проблем якості продукції, що виготовляється, та можливих шляхів їх вирішення. Для досягнення мети необхідно уточнити роль сертифікаційних випробувань у забезпеченні якості та безпечності товарів, сформувати визначення ефективності сертифікації та обгрунтувати можливість вирішення комплексу питань сертифікації.

Виклад основного матеріалу. Перш ніж перейти до розгляду ризиків випробовувальної лабораторії органу оцінки відповідності, слід уточнити визначення основних понять у сфері сертифікації та якості продукції.

Клієнт (client) - організація або особа, яка є відповідальною перед органом із сертифікації за забезпечення того, що сертифікаційні вимоги, зокрема вимоги до продукції, виконуються.

Оцінювання (evaluation) - комбінація функцій діяльності з оцінки відповідності, таких як відбирання та визначання.

Продукція (product) - результат процесу.

Примітка. В ISO 9000:2005 визначено чотири узагальнені категорії продукції:

- послуги (наприклад, транспортування) (див. визначення в 3.6);

- інтелектуальна продукція (наприклад, комп'ютерна програма, словник);

- технічні засоби (наприклад, двигун, механічна деталь);

- перероблені матеріали (наприклад, мастило).

Процес (process) - сукупність взаємопов'язаних або взаємодіючих видів діяльності, що перетворюють входи на виходи.

Послуга (service) - результат принаймні однієї дії, що обов'язково виконується у взаємодії між постачальником та замовником, який зазвичай є нематеріальним.

Сертифікаційні вимоги (certification requirement) - визначені вимоги, зокрема вимоги до продукції, які виконує клієнт як умову отримування або підтримування сертифікації.

Вимога до продукції (product requirement) - вимога, що безпосередньо пов’язана з продукцією та встановлена в стандартах або інших нормативних документах, визначених схемою сертифікації.

Примітка. Вимоги до продукції можуть бути визначені в таких нормативних документах, як регламенти, стандарти і технічні специфікації.

Схема сертифікації (certification scheme) - система сертифікації, що стосується певної продукції, до якої застосовують однакові встановлені вимоги, конкретні правила та процедури.

Власник схеми (scheme owner) - особа або організація, відповідальна за розроблення та підтримування конкретної схеми сертифікації [1, с. 3].

Орган з сертифікації (certification body) - орган оцінювання відповідності третьої сторони, який керує схемами сертифікації[1, с. 3].

У довгостроковий період існує тенденція до послідовного підвищення якості продукції. Це об'єктивний процес, спричинений дією закону зростаючих потреб. Проте згадана тенденція на окремих відрізках часу не в змозі рельєфно проявитися через існування специфічного взаємозв'язку обсягу пропозиції продукції і вимог споживачів до iï якості. В умовах дефіциту, коли пропозиція відстає від попиту, вимоги до якості продукції знижуються, і нерідко істотно. Водночас із насиченням ринку продукцією іiі якість виступає на перший план, всезростаючі вимоги до неї поступово стають однією з основних рушійних сил виробництва [2].

Досягнута якість продукції - це сукупність усіх її властивостей, що можуть характеризувати спроможність даної продукції задовольнити потреби кінцевого споживача відповідно до ії цільового призначення. I чим вищою буде якість продукції, тим повніше задовольняються потреби споживача.

Основними причинами, що визначають необхідність забезпечення і підвищення якості, $є$ :

- безперервне і кількісне зростання потреб (особистих, суспільних, виробничих), їх якісний розвиток і видозміна; 
- зростання ролі і темпів науково-технічного прогресу в розвитку науки, техніки, виробництва, економіки;

- удосконалення та ускладнення конструкцій виробів, що випускаються, підвищення значущості функцій, які виконуються ними;

- збільшення обсягу виробництва продукції і, як наслідок, можливе зростання вартості браку;

- посилення вимог до інтенсифікації виробництва і підвищення його ефективності;

- посилення конкуренції на внутрішніх і світових ринках [3, с. 39].

Сертифікаційні випробування проводять на території та обладнанні замовника або виробника за умов проведення попередньої атестації випробувального обладнання за присутності експерта із сертифікації під час випробувань для забезпечення їх об'єктивності. За результатами випробувань складають протокол, у якому відображено результати випробувань заявленої продукції та який є офіційним документом, що служить основою для видачі сертифіката відповідності.

На міжнародному ринку в поняття якості включається все, що сприймається споживачами, а саме: фізичні властивості; функціональні характеристики; конструктивні й ергономічні параметри; безпека користування товаром; упаковка; дозування.

Рівень якості являє собою відносну характеристику якості продукції, що базується на порівнянні значень показників якості оцінюваної продукції з базовими значеннями відповідних показників. Іншими словами, рівень якості продукції - це кількісна характеристика міри придатності того або іншого виду продукції для задоволення конкретного попиту на неї порівняно з відповідними базовими показниками за фіксованих умов споживання [4, с. 44].

Продукція, що проходить сертифікаційні випробування, може знаходитися в двох станах:

1) відповідає встановленим вимогам;

2) не відповідає встановленим вимогам.

Під час проведення сертифікації можливо виділити два основні етапи, що зображені на рис. 1.

1. Перший етап - це попередня перевірка продукції.

2. Другий етап - остаточний аналіз виробу з урахуванням отриманих даних.

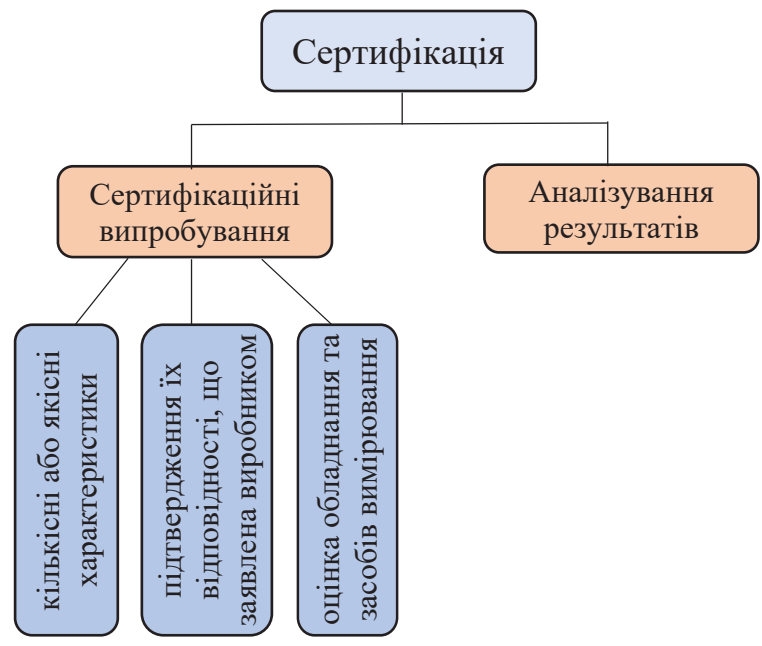

Рис. 1. Основні етапи сертифікаціï 
Порядок внутрішньої організації сертифікаційних випробувань у лабораторіях (випробувальних центрах) визначається планом проведення випробувань, методом відбору зразків, процедурою обробки даних та правилами прийняття рішення

Серед методів підтвердження відповідності можливо виділити такі:

\section{1. Проведення вимірювань.}

За допомогою цього методу можливо визначити значення отриманого параметра або величини й того, якою мірою отримані результати вимірювання близькі до дійсного значення. Показники точності можливо визначити за допомогою допустимої похибки вимірювань.

\section{2. Випробування.}

За допомогою цього методу можливо визначити значення отриманого параметра або величини за заданих факторів та режимів, що впливають на них, та які визначають значення параметра або величини й того, якою мірою отримані результати вимірювання близькі до дійсного значення за заданих факторів и режимів випробувань. Показник точності визначають як суму похибок факторів, режиму та вимірювань.

\section{3. Контроль.}

За допомогою цього методу можливо встановити, що параметр або величина за заданих факторів, що впливають, та режимів випробувань знаходиться в допуску та ступінь достовірності знаходження величини або параметра не виходить за допустимі межі.

Оскільки сертифікація $є$ інструментом захисту інтересів споживача, то під час проведення сертифікації на основі результатів сертифікаційних випробувань виноситься рішення не про конкретну партію продукції (як за результатами звичайних контрольних та здавальних випробувань), а про можливість постачальника взагалі виробляти продукцію такого виду відповідно до вимог споживача. Тому і зміст робіт із сертифікації істотно відрізняється від робіт, що виконуються під час випробувань [5, с. 67].

У разі отримання у процесі сертифікації позитивного результату споживачу видається документ, який називається «сертифікат відповідності» та який підтверджує відповідність продукції всім мінімальним вимогам, установленим національним законодавством. Цей документ $є$ перепусткою ринку у законодавчо регульованій сфері.

Сертифікація - важливий чинник забезпечення довіри під час взаємних поставок продукції, а також вирішення таких великих соціальних завдань, як гарантія безпеки продукції, що споживається (використовується), охорона здоров'я і майна громадян, захист навколишнього середовища.

Розвиток сертифікації в загальному економічному просторі різних держав має на увазі взаємне визнання результатів сертифікації продукції, що може бути засноване на гармонізації законодавчої бази, використанні єдиних стандартів та взаємновизнаних механізмів встановлення відповідності.

На рівні європейських країн взаємини суб'єктів сертифікації регулюються серією європейських стандартів EN 45000. Багато органів із сертифікації та випробувальних лабораторій, які здійснюють випробування з метою сертифікації, проходять акредитацію, тобто отримують офіційне визнання того, що вони можуть проводити певні види діяльності. Зокрема, акредитація може полягати в тому, що орган з акредитації, керуючись стандартами EN 45002 або EN 45010, перевіряє виконання випробувальною лабораторією або органом із сертифікації стандартів EN 45001 або EN 45011 відповідно [5, с. 67].

Ще одним способом підтвердження відповідності продукції необхідним параметрам є декларація про відповідність, у якій постачальник, згідно зі стандартом EN 45014, заявляє під свою виняткову відповідальність про те, що конкретна продукція відповідає конкретному стандарту або іншому нормативному документу, на який ця декларація посилається. При цьому постачальник повинен забезпечити дотримання необхідних параметрів у допустимих межах та контролювати всі види своєї діяльності на всіх етапах виробництва. 
Якщо постачальник дійсно здатний стабільно виконувати та контролювати виконання вимог стандарту або іншого документа, на який він посилається у декларації про відповідність, то, можливо, цей спосіб встановлення відповідності буде для такого постачальника найбільш економічно доцільним. Проте навіть у разі виконання всіх умов стандарту EN 45014 постачальник може поділити ризик відповідальності за продукцію з органом сертифікації, запросивши сертифікацію цієї продукції незалежною третьою стороною [5, с. 67].

Висновки. Узагальнюючи вищезазначене, можна припустити, що питання забезпечення якості та конкурентоспроможності продукції дає можливість реалізувати відстежуваність процедур із сертифікації, забезпечить достовірність даних, підвищить довіру споживачів до сертифікованої продукції, дасть змогу зменшити витрати та час на проведення сертифікаційних випробувань. Сертифікація як шлях удосконалення розвитку підприємництва не повинна створювати зайвих перешкод у торгівлі та має перетворитися на ефективний засіб боротьби на зовнішніх ринках постачальників. Тому вивчення та вдосконалення процедури сертифікації дасть змогу виробнику мати документальне підтвердження якості своєї продукції.

\section{Список використаних джерел:}

1. ДСТУ EN ISO/I EC 17065:2019. Оцінка відповідності. Вимоги до органів з сертифікації продукції, процесів та послуг.

2. Браун М., Георги Д. Управление качеством: затраты и выгоды. Проблемы теории и практики управления. 2000. № 1. С. 34-36.

3. Вандяк Н.П. Значення підвищення якості продукції на підприємствах харчової промисловості. Стратегія ресурсозберігаючого використання аграрно-економічного потенціалу на основі активізаџї інновачійно-інвестиційної діяльності - об'єктивна передумова інтеграиії країни у світове співтовариство : збірник тез доповідей міжнародної науково-практичної конференції, 18 травня 2007 р. Тернопіль, 2007. С. 38-40.

4. Цилюрик Г.І. Якість товару - ключовий важіль забезпечення його конкурентоспроможності. Фінанси і облік України. 2008 № 3. С. 42-45.

5. Гвоздева С.М. Сертификация как инструмент повышения качества продукции. Известия Саратовского университета. Серия «Экономика. Управление. Право». 2010. С. 63-67.

\section{References:}

1. DSTU EN ISO/I EC 17065:2019 Ocinka vidpovidnosti. Vymoghy do orghaniv z sertyfikaciji produkciji, procesiv ta poslugh [DSTU EN ISO/I EC 17065:2019 Conformity assessment. Requirements for bodies certifying products, processes and services].

2. Braun M., Georgi D. (2000) Upravlenie kachestvom: zatraty i vigodi [Quality management: costs and benefits]. Problemyteorii i praktiki upravlenija, no. 1, pp. 34-36.

3. Vandjak N.P (2007) Znachennja pidvyshhennja jakosti produkciji na pidpryjemstvakh kharchovoji promyslovosti [The value of the increase in the quality of products at the enterprises of the grub industry]: Proceeding of the Strateghija resursozberighajuchogho vykorystannja aghrarno-ekonomichnogho potencialu na osnovi aktyvizaciji innovacijno-investycijnoji dijaljnosti-ob'jektyvna peredumova integhraciji krajiny v svitove spivtovarystvo (Ukraine, Ternopilj, May 18, 2007), pp. 38-40.

4. Cyljuryk Gh.I. (2008) Jakistj tovaru - kljuchovyj vazhilj zabezpechennja jogho konkurentospromozhnosti [The quality of the product is the key importance of securing its competitiveness]. Finansy i oblik Ukrajiny, no. 3, pp. 42-45.

5. Gvozdeva S.M. (2010) Sertifikacija kak instrument povyshenija kachestva produkcii [Certification as a tool to improve product quality]. Izvestija Saratovs'kogo univrsiteta. Novaja serija. Serija jekonomika. Upravlenie. Pravo, pp. 63-67. 